\section{Rapid Preparation of Limited Biological Samples for Small-volume PCR}

\author{
B.A. Neilan, ${ }^{1,3}$ A. Gurvitz, ${ }^{1}$ \\ D.A. Leigh, ${ }^{1}$ L.Y.C. Lai, ${ }^{2}$ and \\ B. McDonald ${ }^{1}$ \\ ${ }^{1}$ Molecular Genetics Unit, Prince of \\ Wales Hospital, Randwick, 2031, \\ Australia; ${ }^{2}$ School of Community \\ Medicine, University of New South \\ Wales, Kensington, 2033, Australia
}

\footnotetext{
${ }^{3}$ Present address: School of Microbiology and Immunology, University of New South Wales, Kensington, 2033, Australia.
}

The ability to analyze the DNA of a biological sample has revolutionized the fields of genetic disease diagnosis and forensic medicine. Small-volume PCR with extremely rapid cycling parameters, known as capillary PCR, has enabled complete DNA analysis of multiple loci in a few hours. ${ }^{(1)}$ Traditional organic extraction of DNA from a chorionic villus sample (CVS) for prenatal diagnosis takes several hours and small biopsies yield little or no amplification template. Similarly, fresh or dried blood needs to be acquired in relatively large quantities and treated extensively for extraction of enough viable material in a DNA study. ${ }^{(2)}$ Thus, the small-volume reactions, apart from being rapid and economically attractive, provide increased specificity to DNA amplification. This is a direct result of the decreased times at temperatures between those programmed for the cycling procedure.

We describe a 10 -min protocol for the partial extraction of genetic material from microgram amounts of tissue, including whole blood and fetal products, to complement the speed and sensitivity of capillary PCR. Although these methods, as outlined in this report, are used in a purely diagnostic manner, the advantages of specificity and speed are useful for the rapid optimization of new primer and target combinations in research.

\section{METHODS}

Fresh, thawed, or dried (Guthrie spot) whole blood was initially and crudely hemolyzed to remove inhibitors of DNA amplification reactions, such as hemoglobin. ${ }^{(3)}$ Aliquots of $10 \mu \mathrm{l}$ of blood or approximately $8 \mathrm{~mm}^{2}$ of blood-stained material were resuspended in $200 \mu \mathrm{l}$ of $10 \mathrm{~mm}$ Tris- $\mathrm{HCl}$ ( $\mathrm{pH} \mathrm{7.8),} 1 \mathrm{~mm}$ EDTA, and $0.5 \%$ NP-40 (TED). Samples were then centrifuged to form a pellet of cellular material and the procedure was repeated after resuspending the pellet in $200 \mu \mathrm{l}$ of TED. The matrix of a dried blood spot was left in the tube during this procedure. Samples from a CVS (1 $\mathrm{mg}$; equivalent to a single villus strand) or amniotic fluid cells (1 mg) were centrifuged to a pellet and the supernatant was decanted. All samples, regardless of origin, were then treated identically. Routinely, $40 \mu \mathrm{l}$ of $0.1 \%$ Triton X-100 was added to resuspend the pelleted cells. Partial digestion of cell membranes and denaturation of proteins in the sample was achieved by addition of $10 \mu \mathrm{l}$ of $0.4 \mathrm{M} \mathrm{NaOH}$ and heating to $95^{\circ} \mathrm{C}$ for 5 min. The solution was neutralized with $10 \mu$ l of $1 \mathrm{~m}$ Tris ( $\mathrm{pH} 7.5$ ). Sufficient DNA template for capillary PCR was obtained from $2 \mu \mathrm{l}$ of this crude extract.

PCR amplification was carried out in a buffer containing $67 \mathrm{~mm}$ Tris- $\mathrm{HCl}(\mathrm{pH}$ 8.8) $16 \mathrm{~mm}\left(\mathrm{NH}_{4}\right)_{2} \mathrm{SO}_{4}, 0.45 \%$ Triton $\mathrm{X}-100,200 \mu \mathrm{g} / \mathrm{ml}$ gelatin, $2-3 \mathrm{mM} \mathrm{MgCl}_{2}$, $150 \mu \mathrm{M}$ dNTPs, and 10 pmoles of each oligonucleotide primer. Nondetergent buffers were also used and provided successful amplification. Relatively high levels of Taq DNA polymerase (0.25-0.5 units) (Biotech Int., Australia) and magnesium ions were required in these $10-\mu l$ reactions, probably due to the increased surface area of the reaction vessel compared to tube PCR. Reactions were carried out in heat-sealed positive displacement pipette tips or in ordinary microliter pipette tips overlayed with paraffin oil. Reaction vessels were incubated in the FTS-1S capillary thermocycler (Corbett Research, Australia). Cycle conditions varied for each set of primers, although denaturation at $95^{\circ} \mathrm{C}$ for $5 \mathrm{sec}$, annealing at $60^{\circ} \mathrm{C}$ for $10 \mathrm{sec}$ and $72^{\circ} \mathrm{C}$ for $30 \mathrm{sec}$ to extend represents typical parameters for microsatellite sequence analysis (Figs. 1 and 2). Amplification of adequate quantities of DNA for electrophoretic analysis was achieved in less than 30 cycles for all applications, total amplification time being less than 40 min.

\section{RESULTS AND DISCUSSION}

The analysis of dinucleotide repeats for use as genetic markers has been achieved using the described techniques with electrophoretic analysis of products on polyacrylamide gels (Figs. 1 and 2). Routinely, we have applied rapid extraction of DNA and capillary PCR to the determination of fetal sex, detection of exonic deletions, and genetic linkage via polymorphic restriction fragments or microsatellite sequences for prenatal diagnosis of Duchenne and Becker muscular dystrophy. Multiplex PCR for the detection of up to nine commonly deleted regions in the dystrophin gene ${ }^{(4)}$ has been successfully adapted to both capillary PCR and the use of dried blood spots as amplification template (data not shown). The combination of these methods has also been the basis for genetic studies on 


\section{Technical TipsIIIII}

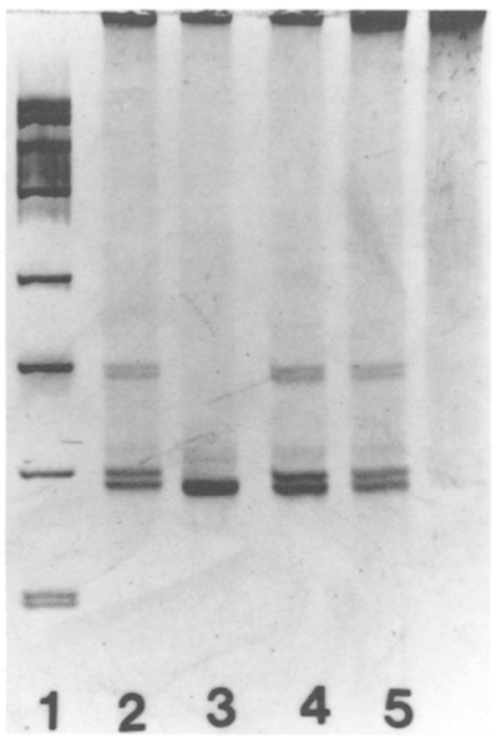

FIGURE 1 Silver-stained 8\% polyacrylamide gel showing dinucleotide repeat alleles at D5S $125^{(7)}$ amplified by capillary PCR for prenatal diagnosis of acute spinal muscular atrophy. (Lane 1) pUC19/HpaII; (lanes 2-5) results for father, proband, and mother's CVS and genomic DNA, respectively. CVS was analyzed directly. Note the heteroduplex formation in heterozygote samples. The alleles are $147 \mathrm{bp}$ and $143 \mathrm{bp}$.

limited samples derived from terminally ill or deceased patients.

These extraction procedures combined with the technology of capillary PCR make analysis of DNA possible in approximately $1 \mathrm{hr}$. The method of sample treatment described is significantly simpler, faster, and more applicable to a wide variety of samples than rapid methods currently in use. ${ }^{(5,6)}$ Time-consuming proteinase $\mathrm{K}$ digestions and successive phenol and chloroform extractions, which may further inhibit PCR, are no longer necessary. Sample preparation by simply boiling in water or nonionic detergents alone has not proven suitable for the applications mentioned. Similarly, microwave treatment of biological samples has not been successful as a fast alternative to PCR template extraction in our laboratory.

The use of the described method has hastened the process of providing information on prenatal diagnoses for carriers of genetic disease, including muscular dystrophy and spinal muscular atrophy, thereby reducing the waiting time and worry for patients. It is now possible to identify genetic mutations much faster and efficiently from archival

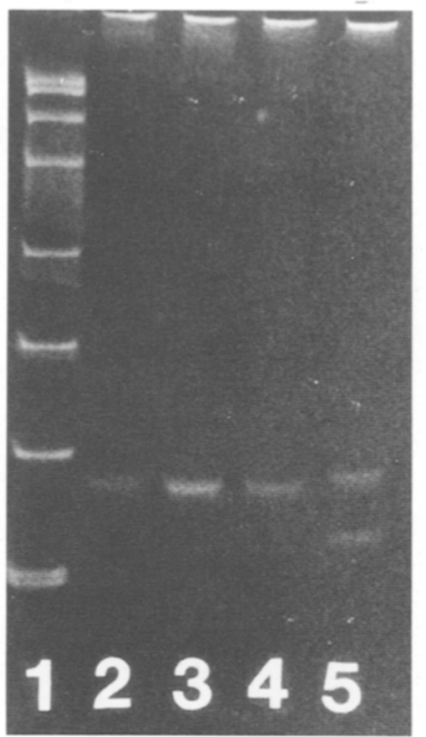

FIGURE 2 Ethidium bromide-stained capillary PCR amplification products from $10-\mu 1$ blood samples. The locus studied is at the distal end of the dystrophin gene. ${ }^{(8)}$ (Lane 1 ) pUC19/HpalI; (lanes 2 and 3) hemizygote allele 2; (lane 4) homozygote allele 2; (lane 5) heterozygote showing alleles 1 and 4 .

blood deposits or extremely small biological specimens.

\section{ACKNOWLEDGMENTS}

This work was supported by the Muscular Dystrophy Association of NSW and the NSW Genetic Service.

\section{REFERENCES}

1. Wittwer, C.T. and D.J. Garling. 1991. Rapid cycle DNA amplification: Time and temperature optimisation. BioTechniques 10: 76-82.

2. Miller, S.A., D.D. Dykes, and H.F. Polesky. 1988. A simple salting out procedure for extracting DNA from human nucleated cells. Nucleic Acids Res. 16: 1215.

3. Panaccio, M. and A. Lew. 1991. PCR based diagnosis in the presence of $8 \%(\mathrm{v} / \mathrm{v})$ blood. Nucleic Acids Res. 19: 1151.

4. Chamberlain, J.S., R.A. Gibbs, J.E. Ranier, P.N. Nguyen, and C.T. Caskey. 1988. Deletion screening of the Duchenne muscular dystrophy locus via multiplex DNA amplification. Nucleic Acids Res. 16: 11141-11156.

5. McCabe, E.R.B. 1991. Utility of PCR for DNA analysis from dried blood spots on filter paper blotters. PCR Methods Applic. 1: 99-106.
6. Williams, C., R. Williams, C. Coutelle, F. Loeffler, J. Smith, and A. Ivinson. 1988. Same-day, first-trimester autenatol diagnosis for cystic fibrosis by gene amplification. Lancet ii: 102-103.

7. Morrison, K.E., R.J. Daniels, G.K. Suthers, G.A. Flynn, M.J. Francis, V.J. Buckle, and K.E. Davies. 1992. High resolution genetic map around the spinal muscular atrophy (SMA) locus on chromosome 5. Am. J. Hum. Genet. 50: 520-527.

8. Beggs, A.H. and L.M. Kunkel. 1991. A polymorphic CACA repeat in the $3^{\prime}$ untranslated region of dystrophin. Nucleic Acids Res. 18: 1931.

Received August 24, 1992; accepted in revised form October 16, 1992. 


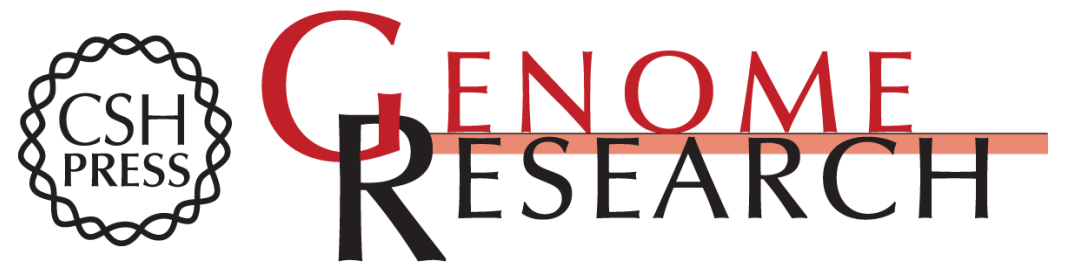

\section{Rapid preparation of limited biological samples for small-volume PCR.}

B A Neilan, A Gurvitz, D A Leigh, et al.

Genome Res. 1993 2: 261-262

Access the most recent version at doi:10.1101/gr.2.3.261

\section{License}

Email Alerting Receive free email alerts when new articles cite this article - sign up in the box at the Service top right corner of the article or click here.

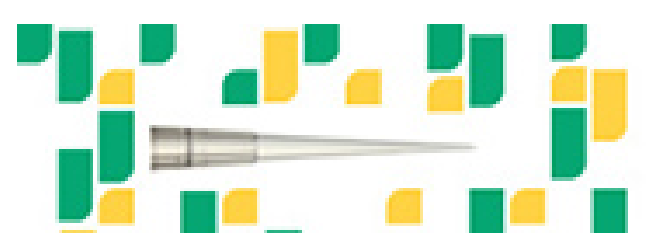

To subscribe to Genome Research go to: https://genome.cshlp.org/subscriptions 